\title{
Utilization of Open Source Spatial Data for Landslide Susceptibility Mapping at Chittagong District of Bangladesh-An Appraisal for Disaster Risk Reduction and Mitigation Approach
}

\author{
Md. Ashraful Islam', Sanzida Murshed' ${ }^{1}$, S. M. Mainul Kabir'1, Atikul Haque Farazi², \\ Md. Yousuf Gazi ${ }^{1}$, Israt Jahan', Syed Humayun Akhter ${ }^{1}$ \\ ${ }^{1}$ Department of Geology, University of Dhaka, Dhaka, Bangladesh \\ ${ }^{2}$ Department of Geology and Mining, University of Barisal, Barisal, Bangladesh \\ Email: ashrafhimel@du.ac.bd
}

How to cite this paper: Islam, M.A., Murshed, S., Kabir, S.M.M., Farazi, A.H., Gazi, M.Y., Jahan, I. and Akhter, S.H. (2017) Utilization of Open Source Spatial Data for Landslide Susceptibility Mapping at Chittagong District of Bangladesh-An Appraisal for Disaster Risk Reduction and Mitigation Approach. International Journal of Geosciences, 8, 577-598.

https://doi.org/10.4236/ijg.2017.84031

Received: February 3, 2017

Accepted: April 25, 2017

Published: April 28, 2017

Copyright $\odot 2017$ by authors and Scientific Research Publishing Inc. This work is licensed under the Creative Commons Attribution International License (CC BY 4.0).

http://creativecommons.org/licenses/by/4.0/

c) (i) Open Access

\begin{abstract}
Since creation of spatial data is a costly and time consuming process, researchers, in this domain, in most of the cases rely on open source spatial attributes for their specific purpose. Likewise, the present research aims at mapping landslide susceptibility at the metropolitan area of Chittagong district of Bangladesh utilizing obtainable open source spatial data from various web portals. In this regard, we targeted a study region where rainfall induced landslides reportedly causes causalities as well as property damage each year. In this study, however, we employed multi-criteria evaluation (MCE) technique i.e., heuristic, a knowledge driven approach based on expert opinions from various discipline for landslide susceptibility mapping combining nine causative factors-geomorphology, geology, land use/land cover (LULC), slope, aspect, plan curvature, drainage distance, relative relief and vegetation in geographic information system (GIS) environment. The final susceptibility map was devised into five hazard classes viz., very low, low, moderate, high, and very high, representing $22 \mathrm{~km}^{2}$ (13\%), $90 \mathrm{~km}^{2}$ (53\%); $24 \mathrm{~km}^{2}$ (15\%); 22 $\mathrm{km}^{2}(13 \%)$ and $10 \mathrm{~km}^{2}(6 \%)$ areas respectively. This particular study might be beneficial to the local authorities and other stake-holders, concerned in disaster risk reduction and mitigation activities. Moreover this study can also be advantageous for risk sensitive land use planning in the study area.
\end{abstract}

\section{Keywords}

Susceptibility Mapping, Open Source Spatial Data, Heuristic Model, Chittagong Metropolitan Area, Geographic Information System (GIS), 


\section{Introduction}

Due to its geographical position and diversified terrain condition, Chittagong district is one of the hotspot areas for landslide hazard in Bangladesh. Each year, landslide events struck this area frequently-resulting in casualties, property damage, and economic loss [1]. Notably, statistics of landslide occurrence indicate one conspicuous thing-there was always a certain time gap between two consecutive landslides in this area. However, surprisingly, in the recent past, the trend and frequency of landslides in this region are found to be increased within a short while, which were triggered by extensive rainfall [2]. Like Dhaka, the capital city of Bangladesh, Chittagong is the second choice for settlement and/or employment among the people for playing a substantial role in the economic development of Bangladesh. Therefore, experts opine that the rapid population growth and eventually rapid urbanization fosters unplanned land use practices and obviously illegal hill cutting, which are the collective facts for enhancing the vulnerability of landslides in this locality [3]. Under the circumstances, landslide intensity zonation using geospatial data (accurate both in scale and resolution) becomes one of the key prerequisites while dealing with the hazard assessment in the study area.

Hazard assessment involves integration of many spatial data and it is obvious that data generation is one of the most time consuming as well as expensive processes. The situation may turn worst while working in Bangladesh. Ironically, despite availability of spatial data in different scales/or formats in several government and non-government agencies of Bangladesh, researchers on this particular domain still have to struggle for acquiring those records until now. As per the Right to Information Act, 2009 (www.moi.gov.bd/RTI/RTI.pdf) citizens of Bangladesh have every right to get admittance to any sorts of information excluding the exceptional cases of threatening the security, integrity and control of Bangladesh. To overcome such constraints, many developed countries have already formulated spatial data infrastructure (SDI) long before. SDI is a platform where relevant organizations share their technology, policies, standards, and human resources with an aim to acquire, process, store, distribute, and improve the utilization of geospatial data [4]. The ultimate goal of SDI is to establish a technology to help finding and sharing geographic information with mutually accepted standards for developing common base themes of data. However, in countries like Bangladesh, where a SDI is lacking, all spatial scientists are enforced to rely mostly on open source data. In spite of lacking of adequate good quality spatial data, several attempts [1] [5]-[10], regarding this aspect (i.e., landslide mapping), have been made in several times in Bangladesh.

Susceptibility refers to the probability of a hazard, considering the numbers of causative factors for that particular hazard. To do susceptibility mapping, geos- 
patial techniques (i.e., GIS and remote sensing) play the prime role in integrating all the causative factors with less biasness and error. Different techniques, e.g., qualitative and/or quantitative, have been employed so far in landslide susceptibility mapping [11]. Among which three viz., heuristic, deterministic and statistical are the most common and popular. Heuristic approach [12]-[19] is basically a knowledge driven technique which considers expert's opinion on the causative factors of landslide during data integration. It is worthwhile to note that heuristic method is subjective, which may vary according to diverse expert's opinion and could only be applicable where historic landslide zones are not clearly identified. On the other hand, deterministic approach mostly confines itself to the slope stability, based on geotechnical measurements [20]-[26]. This particular technique may give better outcomes in a terrain with homogeneous engineering properties. In contrast, statistical approach, so far the most acceptable technique for landslide susceptibility mapping, is adopted by number of studies [27]-[48]. In statistical methods, landslide inventory of past/present landslide is must and based on that the statistical calculations are being made between the intrinsic properties of the landslide affected terrain (e.g., causative factors of landslide). Apart from the aforementioned approaches, though not popular, a number of different methods are being employed: artificial neural network [30] [37] [49][57] and support vector machine models [31] [51] [58]-[61].

Disaster risk reduction (DRR) approaches engross several actions related to the prevention and mitigation of disasters [62] Since DRR is a holistic approach, the first move should be the identification of a particular problem by means of mapping its spatial extent and the estimation of the impending loss caused by the hazard so that the magnitude of disaster can be minimized and the economic loss may be lessen. It is somewhat ironic that in Bangladesh stakeholders who are shouldering the responsibilities of DRR, by and large, devices prevention and mitigation measures with little or no knowledge about the hazard scenario of the corresponding region. Thereby, these approaches though might bring temporary benefits but are not likely to provide long term resilience.

Hence considering the discussed issues, the present research focuses primarily on the landslide susceptibility mapping at Chittagong metropolitan areas with knowledge based heuristic approach within GIS environment, using a number of free/or open spatial data sets. In addition, the current research theme could be an insight for the spatial scientists of the country (e.g., agriculture, forestry, urban, etc.), who are short of sufficient fund for data generation in their respective field of research. Moreover, based on the final hazard map this research also attempted to identify related causes of landslides and their probable prevention and mitigation approaches for long term sustainability of the study area.

\section{Study Area}

Among all the hilly districts, Chittagong has drawn major attention of the multidisciplinary research groups due to its diversified landscape (from terrestrial high land to low land i.e., coastal areas). This particular area is in potential threat 
of various hazards for instance, cyclone, the most devastating and common one; earthquake, though not frequent but the region itself befalls in the high vulnerable zone (i.e., seismic zone 2); and landslide, the current leading concern of the local habitants. Unlike the other part of Bangladesh, Chittagong district is characterized by diversified geological and geomorphological units as well. Hills are the most vulnerable part of this region that comprises the western extension of the Indo-Burman range, the upshot of Indian and Asian plate convergence.

On the contrary, the extreme western part of the area is dominated by coastal environments that frequently experiences cyclonic storm and coastal erosion. Climatic condition of this region is tropical, having monsoon season from June to October. There, average rainfall recorded as $>2540 \mathrm{~mm}$ during this season. An increasing trend in the rainfall pattern has been observed since the last decade that eventually amplifies the vulnerability of rainfall induced landslide [2]. The current research concern attributes to landslide hazard assessment as there is no strict hill management policy within this area; encouraging many informal settlements along the landslide-prone hill-slopes in Chittagong. Geographically, the area is situated within $21^{\circ} 51^{\prime}$ and $23^{\circ} 00^{\prime}$ North latitude and between $91^{\circ} 20^{\prime}$ and $91^{\circ} 14^{\prime}$ East longitude (Figure 1). Recent census [63] indicates that population has increased to $\sim 7,616,352$ with a density of $3424 / \mathrm{km}^{2}$.

As stated earlier, population of Chittagong district increases substantially, just next to the capital city of Dhaka, because of better employment opportunities, hence this particular region is under potential threat of landslides. Here the scenario arrives-the authoritative bodies consider these settlements as illegal, while the settlers claim themselves as legal occupants, rendering acute land tenure conflict among the formal authorities, the settlers, and the local communities over the past few decades [2]. Ultimately, this kind of conflict has weakened the institutional arrangement for reducing the landslide vulnerability in Chittagong City. There is a north-south trending hill range across the city, where there at the foothills lower income people are living in the unplanned settlements and slums in a risky situation [10]. In the recent past, occurrence of a number of landslides (Table 1) in the study area due to sudden increase of rainfall within a short while (i.e., 2 to 4 days) indicates heavy rainfall as one of the crucial causes of landslide in this locality.

\section{Materials and Method}

\subsection{Spatial Data Source}

All the spatial data sourced in the study being obtained from various open source web portals are given in the Table 2 and a flow chart in Figure 2 exhibits entire working process of this research. SRTM DEM (version 2) having spatial resolution of 30 meter sourced from United States geological survey (USGS) operated website Earth explorer (https://earthexplorer.usgs.gov/) for the preparation of various topographic parameters viz., slope, aspect, plan curvature and relative relief of the current analysis. Using the same web portal a recent medium resolution (i.e., $30 \mathrm{~m}$ ) orthorectified Landsat image, dated on 11 January 


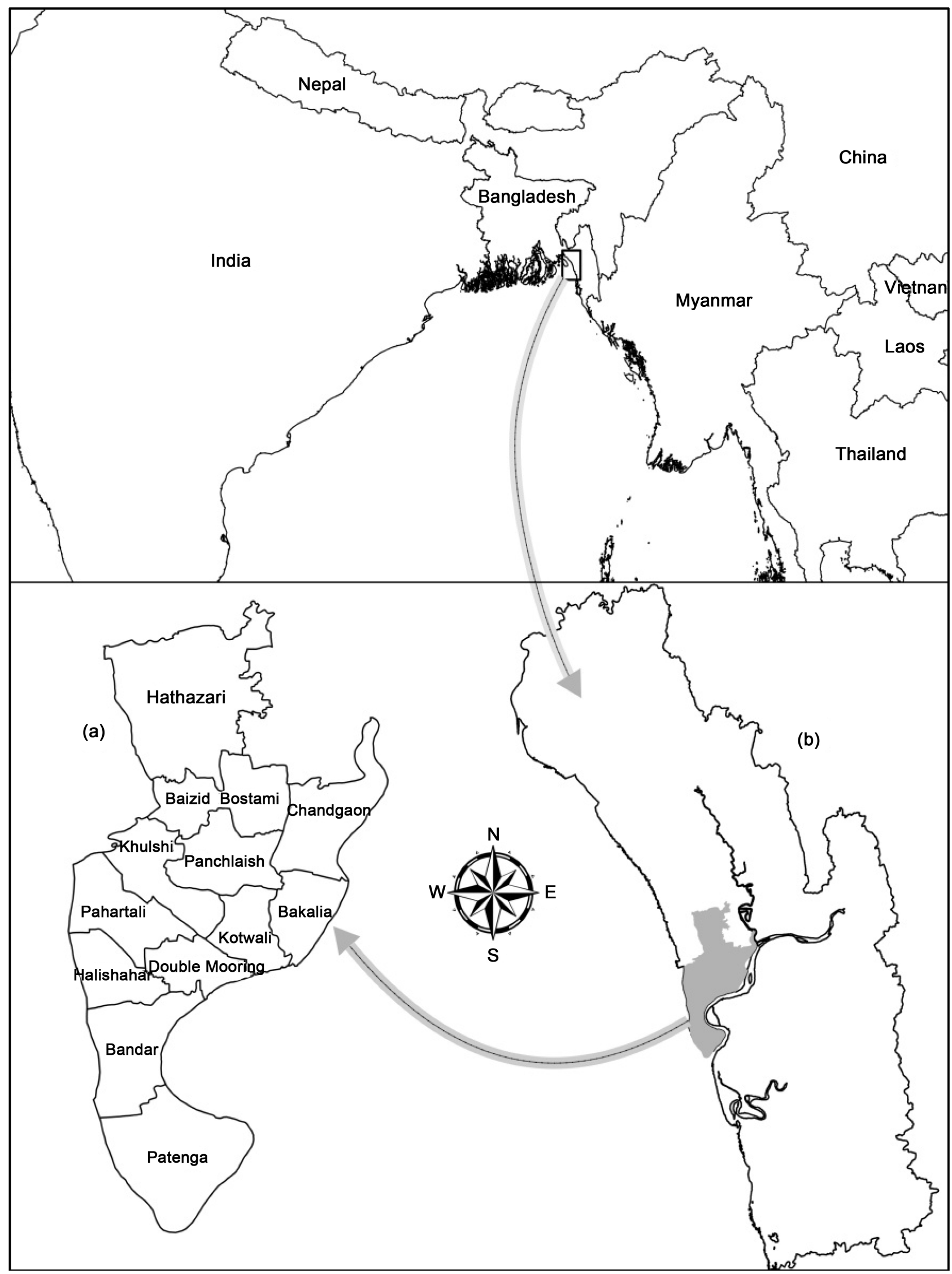

Figure 1. Location map of the studied chittagong metropolitan area (http://www.fao.org/geonetwork/srv/en/main.home). 
Table 1. Lists of the major landslides occurred in chittagong metropolitan area.

\begin{tabular}{|c|c|}
\hline Year & Description \\
\hline 1999 & $\begin{array}{l}\text { Landslide occurred in Chittagong Metropolitan area on } 13^{\text {th }} \text { August } 1999 \text { claiming the } \\
\text { life of } 10 \text { people. }\end{array}$ \\
\hline 2000 & $\begin{array}{l}\text { At least } 13 \text { people were killed and } 20 \text { injured in landslide incidents on the Chittagong } \\
\text { University campus and other parts of Chittagong City on } 24^{\text {th }} \text { June, } 2000 \text {. The } \\
\text { landslides damaged property worth } \sim 10,000 \$ \text {. }\end{array}$ \\
\hline 2005 & $\begin{array}{l}\text { Three children were killed and another was injured in a landslide at Shantinagar area } \\
\text { adjacent to the Bangladesh Cooperative Housing Society in Bayezid Bostamithana in } \\
\text { the port city on } 31^{\text {st }} \text { October } 2005 \text {. }\end{array}$ \\
\hline 2007 & $\begin{array}{l}\text { At least } 128 \text { people were killed and hundreds more injured and missing and a lot of } \\
\text { property damaged as torrential rains sparked a series of devastating landslides at } \\
\text { Baizid Bostami, Kushumbagh, Motijharna, Sikandarpara, Lebubagan, Kochuarghona, } \\
\text { Workshopghona, Chittagong University campus, Hathazari in Chittagong } \\
\text { Metropolitan city on } 11^{\text {th }} \text { June, } 2007 \text {. }\end{array}$ \\
\hline 2008 & $\begin{array}{l}\text { A rain-induced mudslide at Matijharna in Chittagong Metropolitan city on } 18^{\text {th }} \\
\text { August, } 2008 \text { left } 11 \text { people. This event destroyed } 14 \text { houses of a slum built on a hillside } \\
\text { from which the government was relocating families apprehending the danger. }\end{array}$ \\
\hline 2012 & $\begin{array}{l}\text { At least } 13 \text { people were killed at Khulshi, North Pahartoli, Banshkhali, Ambagan and } \\
\text { Hathazari in Chittagong city and Banshkhali area in land-slide on } 26^{\text {th }} \text { June, } 2012 \text { due } \\
\text { to heavy torrential rains while wall collapse and electrocution. landslide at Yasin } \\
\text { Colony in Khulshi area had buried } 20 \text { houses in Chittagong. }\end{array}$ \\
\hline 2013 & $\begin{array}{l}12 \text { people died in separate landslides in different parts of Chittagong City area on } 27^{\text {th }} \\
\text { July, } 2013 \text { and the areas that suffered more includes Halishahar, Pahartali, } \\
\text { Khulshi and Bakalia. }\end{array}$ \\
\hline
\end{tabular}

Source: Banglapedia (the national encyclopedia of Bangladesh), bdnews24.com, www.coastbd.org.

2015 was downloaded for LULC and geomorphological mapping. Geology information was obtained from downloadable GIS data of Bangladesh which had been retrieved from U.S. Geological Survey Open-File Report (OFR-97-470-H).

\subsection{Spatial Techniques Employed}

Prior to the LULC map creation by means of unsupervised classification scheme few image enhancement techniques (e.g., histogram equalization and contrast stretching) were employed over the satellite image. Later, employment of accuracy assessment technique over the final outcome, using ground control points (GCP): collected from field survey, yielded $\sim 85 \%$ accuracy. Using the same satellite imagery, a geomorphology map was created by means of on screen visual interpretation scheme, which was subsequently cross checked by field survey and auger hole lithology information collected from field investigations.

Apart from this, a vegetation map was generated by means of spectral enhancement techniques like NDVI. The engendered map comprises three major vegetation classes as high, moderate and low. Slope, aspect and plan curvature maps were prepared from DEM file using spatial analyst tool of ArcGIS (version 10.1). Prior to execution of these functions a median filter was run over the entire DEM to minimize and remove artifacts. For the relative relief mapping, the 
Table 2. Showing the analyzed parameters with their sources and spatial processing.

\begin{tabular}{|c|c|c|}
\hline Parameters & Spatial techniques employed & Source \\
\hline $\begin{array}{l}\text { [1] Slope } \\
\text { [2] Aspect }\end{array}$ & $\begin{array}{l}\text { Spatial analysis ArcGIS (version } \\
\text { 10.1) functions }\end{array}$ & \\
\hline $\begin{array}{l}\text { [3] Plane curvature } \\
\text { [4] Distance to } \\
\text { drainage }\end{array}$ & $\begin{array}{l}\text { Spatial hydrologic analyst and } \\
\text { Euclidean distance function }\end{array}$ & $\begin{array}{l}\text { Shuttle Radar Topography Mission (SRTM) } 30 \mathrm{~m} \text { Digital elevation model } \\
\text { (DEM). } \\
\text { Earth Explorer } \\
\text { https://earthexplorer.usgs.gov/ }\end{array}$ \\
\hline [5] Relative relief & $\begin{array}{l}\text { Grid based (Fishnet tool) elevation } \\
\text { range using Zonal statistics tool }\end{array}$ & \\
\hline [6] LULC & $\begin{array}{l}\text { Unsupervised classification } \\
\text { techniques in ERDAS imagine } \\
\text { (version 14)along with field } \\
\text { checking. }\end{array}$ & \\
\hline [7] Geomorphology & $\begin{array}{l}\text { Visual interpretation (Landsat 8) } \\
\text { along with field checking }\end{array}$ & $\begin{array}{l}\text { Landsat } 8 \text { OLI \& TIRS } \\
\text { (Dated on } 11 \text { January 2015) } \\
\text { Earth Explorer }\end{array}$ \\
\hline [8] Vegetation & $\begin{array}{l}\text { Spectral enhancement techniques } \\
\text { using Normalized difference } \\
\text { vegetation index (NDVI) in } \\
\text { ERDAS imagine (version 14) along } \\
\text { with field checking }\end{array}$ & https://earthexplorer.usgs.gov/ \\
\hline [9] Geology & $\begin{array}{l}\text { Clipped from GIS file (i.e., shapefile } \\
\text { of Bangladesh Geology) }\end{array}$ & $\underline{\text { https://pubs.usgs.gov/of/1997/ofr-97-470/OF97-470H/linked_filepaths1.htm }}$ \\
\hline
\end{tabular}

entire study area was divided by $30 \mathrm{~m} \times 30 \mathrm{~m}$ grid size alongside each and individual grid filling with elevation range value (e.g., difference between the maximum and minimum altitude). Accomplishment of this particular task involved use of fishnet and zonal statistics along with few other geoprocessing tools in ArcGIS (version 10.1) environment. Further use of the same DEM includes hybridization of a drainage map by means of hydrology processing tools in GIS environment and subsequent preparation of a euclidian distance map from the drainage map. With the help of geoprocessing tool (e.g., clip function) geology map was mined from geology shape file of Bangladesh using boundary of the study area.

\subsection{Assigning Weight Value}

Landslide susceptibility rating for individual parameters and their subclasses is given in Table 3.

It is eminent that the angle of the slope, playing the most vital role in slope stability of a terrain, is directly related to the landslides [64]. Moreover, increase in slope angle potentially raises the level of gravitation induced shear stress in the residual soil. Thus, gentle slope is expected to have a lower frequency of landslide because of, generally, lower shear stress associated with low gradient [36]. In this study, the entire study area was divided into 4 major slope classes viz., $0^{\circ}-5^{\circ}, 5^{\circ}-10^{\circ}, 10^{\circ}-15^{\circ}$ and $>15^{\circ}$. The past landslides put forward an observation that most of the slides were earth/debris flow, where natural slope 


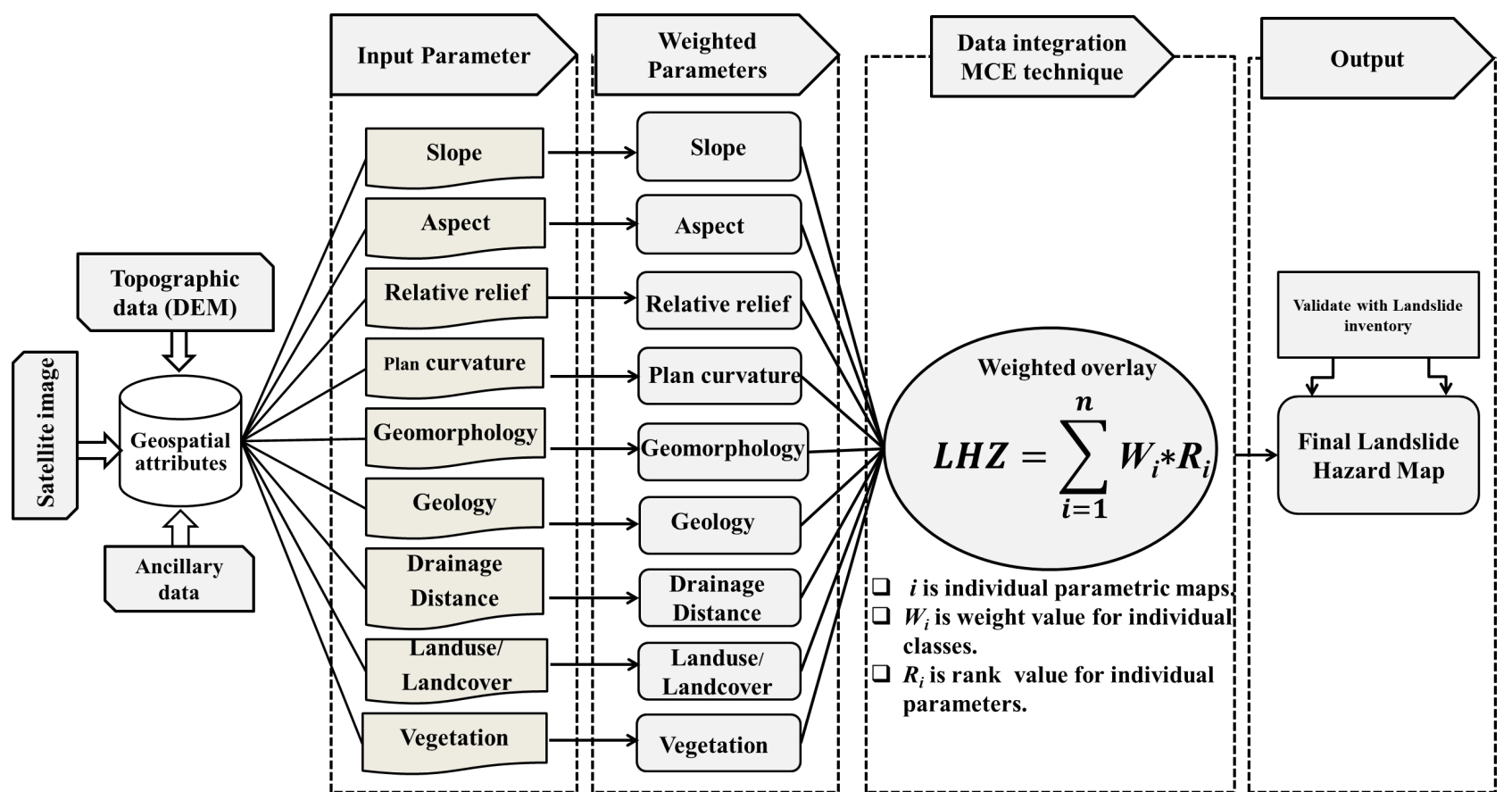

Figure 2. Flow chart showing the methodology of the study.

angles were $>150$. This cognition led us to allotting higher weight value (i.e., 8) to this subclass and moderate weight value to the subclass $100-150$ as 6 . Consecutively, for rest of the subclasses (i.e., $0^{\circ}-5^{\circ}, 5^{\circ}-10^{\circ}$ ) lesser weight values were assigned, i.e., 3 and 4 respectively. Aspect infers exposure to sunlight and drying winds, is another important factor that control the concentration of the soil moisture which, in turn, may control the occurrence of landslides [65]. The aspect map, derived from DEM, is divided into 9 classes as Flat, North, Northeast, East, South-east, South, South-west, West and North-west. Then, from the context that south, south east and south west facing slopes are more open to landslide in the studied area, higher weight values (i.e., 8, 7 and 7) were assigned to these classes, and rest of the subclasses were given lesser weight values within 1 to 3 since those are not likely to pose potential threat. Relative relief is directly proportional to the probability of landslide occurrence as it controls several geologic and geomorphologic processes. The relative relief map of the study area has been divided into 5 classes: < 15 meter, 15 - 25 meter, 25 - 35 meter, 35 - 45 meter and > 45 meter: to show the susceptible relief of the study area. In metropolitan area, landslides occur in areas of relief above 30 meters; with this background knowledge, we put higher weight values to relief classes above 30 meter as 7 to 8 . Concave curvatures concentrate surface water and almost certainly trigger landslide activity, hence assigned high weight value as 6; in contrast, in case of convex curvature surface water will diverge from slope toe thus imposing less threat to landslide, thereby, given low weight value as 3 . There is no substantial influence of flat surface in landslide thus given very low weight values as 2 . Slope stability is indirectly controlled by drainage system with respect to toe cutting, bank erosion and headword erosion of an area [64]. As such any places within the close proximity to major drainage system impose high risk of land- 
Table 3. Knowledge based (Influence on landslide occurrences) weight and rank values for each and individual input parameters.

\begin{tabular}{|c|c|c|c|c|}
\hline Parameters & Sub-Classes & Weight & Rank & Area $\left(\mathrm{km}^{2}\right)$ and $(\%)$ \\
\hline \multirow{4}{*}{ [1] Slope } & $0-5^{\circ}$ & 3 & \multirow{4}{*}{8} & $154(91.70 \%)$ \\
\hline & $5^{\circ}-10^{\circ}$ & 4 & & $11(6.59 \%)$ \\
\hline & $10^{\circ}-15^{\circ}$ & 6 & & $2(1.12 \%)$ \\
\hline & $>15^{\circ}$ & 8 & & $1(0.59 \%)$ \\
\hline \multirow{9}{*}{ [2] Aspect } & Flat & 1 & \multirow{9}{*}{5} & $32(19 \%)$ \\
\hline & North & 2 & & $10(5.96 \%)$ \\
\hline & North-east & 2 & & $19(11.3 \%)$ \\
\hline & East & 3 & & $20(11.92 \%)$ \\
\hline & South-east & 7 & & $18(10.71 \%)$ \\
\hline & South & 8 & & $17(10.13 \%)$ \\
\hline & South-west & 7 & & $18(10.72 \%)$ \\
\hline & West & 2 & & $17(10.13 \%)$ \\
\hline & North-west & 3 & & $17(10.13 \%)$ \\
\hline \multirow{5}{*}{ [3] Relative Relief } & $<15$ meter & 2 & \multirow{5}{*}{6} & $108(64.30 \%)$ \\
\hline & 15 - 25 meter & 4 & & $13(7.71 \%)$ \\
\hline & 25 - 35 meter & 6 & & $19(11.31 \%)$ \\
\hline & 35 - 45 mete & 7 & & $18(10.72 \%)$ \\
\hline & $>45$ meter & 8 & & $10(5.96 \%)$ \\
\hline \multirow{3}{*}{ [4] Plan Curvature } & Concave & 6 & \multirow{3}{*}{6} & $58(34.52 \%)$ \\
\hline & Flat & 2 & & $53(31.54 \%)$ \\
\hline & Convex & 3 & & $57(33.92 \%)$ \\
\hline \multirow{5}{*}{ [5] Distance from Drainage } & $<50$ meter & 8 & \multirow{5}{*}{3} & $12(7.15 \%)$ \\
\hline & $50-100$ & 5 & & $11(6.54 \%)$ \\
\hline & $100-150$ & 3 & & $12(7.15 \%)$ \\
\hline & $150-200$ & 2 & & $19(11.30 \%)$ \\
\hline & $>200$ meter & 1 & & $114(67.86 \%)$ \\
\hline \multirow{4}{*}{ [6] Land use/land cover } & Vegetation & 5 & \multirow{4}{*}{4} & $25(14.89 \%)$ \\
\hline & Cultivated land & 2 & & $95(56.55 \%)$ \\
\hline & Barren Land & 8 & & $41(24.40 \%)$ \\
\hline & Urban & 3 & & $7(4.16 \%)$ \\
\hline \multirow{3}{*}{ [7] Vegetation } & Sparse vegetation & 8 & \multirow{3}{*}{3} & $48(28.57 \%)$ \\
\hline & Moderate vegetation & 5 & & $64(38.09 \%)$ \\
\hline & High vegetation & 3 & & $56(33.34)$ \\
\hline \multirow{5}{*}{ [8] Geology } & Bhuban/BokaBill Formation & 6 & \multirow{5}{*}{3} & $21(12.5 \%)$ \\
\hline & Dihing Formation & 4 & & $13(7.71 \%)$ \\
\hline & Tidal deltaic deposits & 1 & & $19(11.32 \%)$ \\
\hline & Tipam/DupiTila Formation & 8 & & $55(32.74 \%)$ \\
\hline & Valley alluvium and colluvium & 3 & & $60(35.73 \%)$ \\
\hline \multirow{7}{*}{ [9] Geomorphology } & Fluvio tidal plain & 2 & \multirow{7}{*}{7} & $39(23.21 \%)$ \\
\hline & Foreshore & 1 & & $4(2.38 \%)$ \\
\hline & Inter tidal plain & 1 & & $6(3.57 \%)$ \\
\hline & Piedmont & 4 & & $100(59.52 \%)$ \\
\hline & Supratidal plain & 2 & & $3(1.78 \%)$ \\
\hline & Tertiary hills & 7 & & $8(4.77 \%)$ \\
\hline & Valley & 5 & & $8(4.77 \%)$ \\
\hline
\end{tabular}

slides than areas that located far. Keeping this in mind the drainage distance map has been classified as <50 m, $50-100 \mathrm{~m}, 100-150 \mathrm{~m}, 150-200 \mathrm{~m}$ and $>$ $200 \mathrm{~m}$ and assigned weight values as 8, 5, 3, 2 and 1 respectively. LULC is related 
to risk and vulnerability of disaster, hence plays a vital role in landslide initiation. In general, the area was categorized as four classes' viz., vegetation, cultivable land, barren land and urban areas. Among them, the barren areas were given highest weight value as 8 , because, indirectly, the barren and sparsely vegetated areas exhibit faster erosion and more instabilities than forest area [18] [36] [63]. Whilst the class vegetation seems to be less risky to landslide, however, in this study, we adopted moderate weight value because of substantial occurrence of vegetation in the hilly areas of the study location. On the other hand, the rest two classes-the cultivable and the urban areas-were assigned lower weight values (i.e., 2 and 3 respectively). Vegetation cover renders the stability of a slope by reducing soil erosion and direct infiltration of rainwater, eventually increasing the strength of near surface soil and decreasing the potential of landslide incidence. Therefore, slopes having sparse vegetation were assigned high weight value as 8 whereas moderate and high vegetation were given moderate (e.g., 5) to low (e.g., 3) weight values in this study. Slope strength of a hilly terrain is directly governed by geological attributes like lithology. Among the five geological units encountered in the study area Tipam/DupiTila formation, being comprised of, loose and less resistive sandstone layers account for maximum landslides in the study area; and thus alloted highest weight values 8 in context of landslide. Bhu-ban/Bokabill formation, on the other hand, are consist of hard and compact shale and believed to be comparatively less susceptible to landslide. Thereby, they are assigned moderate weight value as 6 in this study. Again, the Dihing Formation characterized by dominantly sand and clay lithology has given weight value 4. Rest of the units i.e., tidal deposit, valley alluvial and colluvial deposits, since not likely to pose any threat of landslides, are given very less weight values as 1 and 3 respectively. Morphological settings of an area aids in conjecturing idea about future landslides, considering the historic occurrence of the hazard. In this study, seven geomorphologic units viz., tertiary hills, valley, piedmont plain, fluvial-tidal plains, supratidal plains, intertidal plains, and foreshores were rated according to their susceptibility to landslide. It is evident from our field observation that the low elevated lands (i.e., piedmont, fluvial-tidal, supratidal, intertidal and foreshore) are trivial for landslide, hence allocated low weight values as 1 to 2 . On the contrary, hilly areas are substantially prone to this hazard due to having higher elevation and slope condition, and therefore were assigned highest weight value as 7 in this study. However, as the complementary part of hills, i.e., the valley, does not ground extensively for landslide, we indexed this geomorphologic unit with moderate weight value as 5 .

\subsection{Model Utilized}

As mentioned previously, the landslide susceptibility index (LSI) mapping used knowledge based heuristic method, hence the maneuver follows conversion of all the spatial datasets to a common scale with weight and rank values (Figure 3). The reason of conversion into a common scale is that all the spatial dataset arrived from diverse source areas of the study region. It would be worthwhile to mention that the knowledge based approach should actually be implemented via 


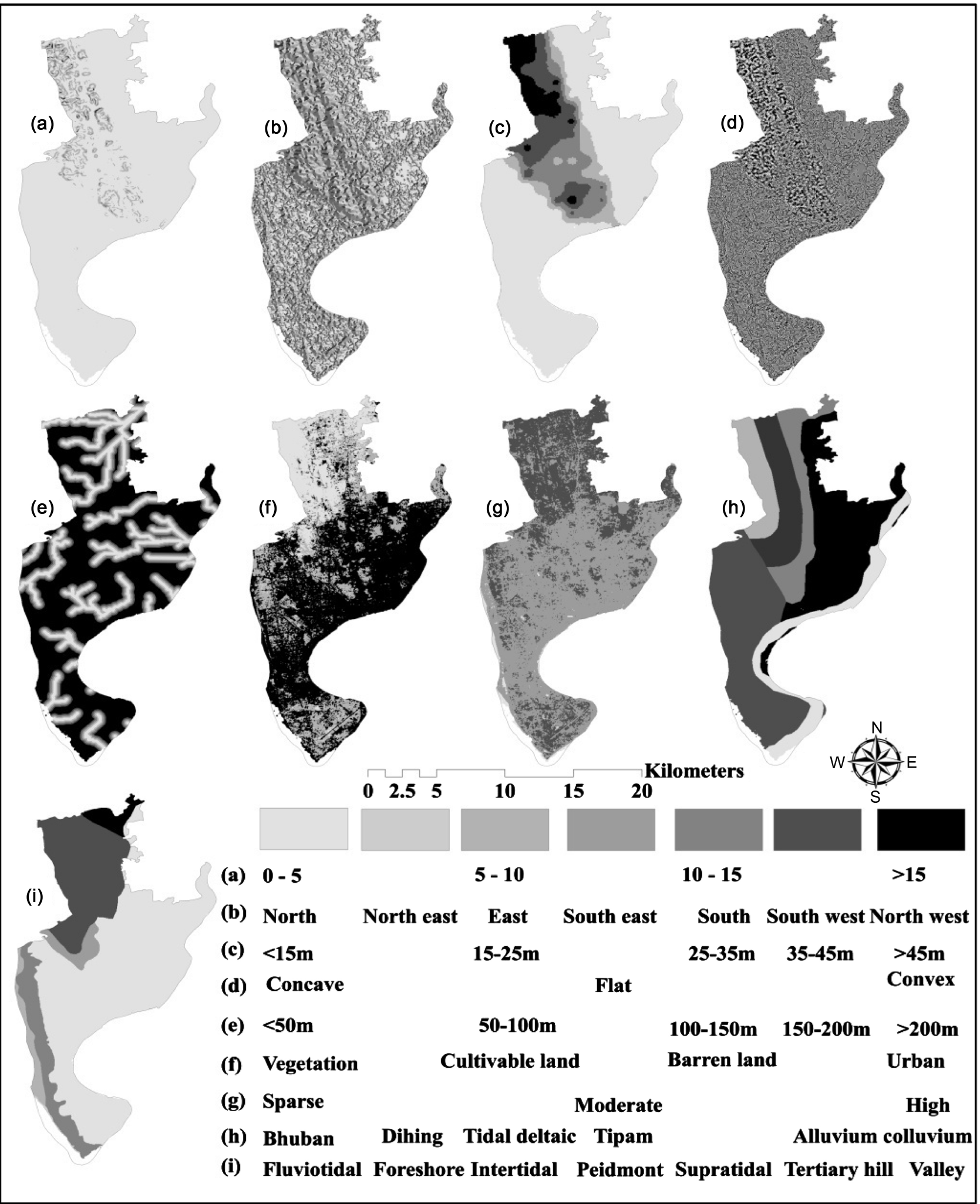

Figure 3. Showing (a) Slope map, (b) Aspect map, (c) Relative relief map, (d) Plan curvature map, (e) Distance from drainage map, (f) LU/LC map, (g) Vegetation map, (h) Geological map and (i) Geomorphological map of Chittagong Metropolitan area.

prior knowledge of landslides in a given area and that knowledge should come from expert's opinions of various discipline. In addition, the LSI procedure as 
well relies on the fundamental assumption that future landslides will occur under conditions similar to those contributing to past landslides. Finally, integration of various thematic parameters in a single hazard index was accomplished by the procedure of weighted liner sum of [66].

$$
L S I=\sum_{i=1}^{n} W_{i} R_{i}
$$

where, $L S I$ is the ultimate landslide susceptibility index, $W_{i}$ is the weight of parameters subclasses, $R_{i}$ is the rank of the each and individual parameter. Once the integration was accomplished, using weighted overlay techniques in ArcGIS (version 10.1) environment, the next step was classification of the final outcomes and at the later stage all the final classified maps were verified with a landslide inventory of the study area.

\section{Results and Discussion}

LSI map depicts the division of land areas into zones of varying degree of stability, based on the estimated significance of the causative factors for inducing instability [19]. After employing knowledge driven weight values to each parameter, all of them were combined subsequently to achieve a landslide susceptibility map that reveals the probability of landslides in the study area. The final susceptibility map exhibits values ranging from 75 to 581, which have more or less well distributed histogram appearance (Figure 4).

Despite of observing the distributed pattern in histogram appearance, we applied three classification methods-natural break, quantile, and equal area intervals-to attain the final hazard map. In this study, we have classified the final map (Figure 5) into five hazard classes: very low (75 - 176), low (176 - 277), moderate (277 - 379), high (379 - 480), and very high (480 - 581): while applying equal area interval method. In quantile classification scheme, the entire area has been categorized as very low (75 - 176), low (132 - 154), moderate (155 - 190), high (191 - 337), and very high (338 - 581). Again, while setting natural break classification on the LSI values, we denoted the classes as very low (75 - 149), low (150 - 213), moderate (214 - 301), high (302 - 395), and very high (396 - 581). Later on, susceptibility maps based on these three classification schemes were subsequently cross checked with the landslide inventory of Chittagong district [67]. We considered the high to very high hazard classes together for the validation of our hazard maps. Total 52 landslide locations were selected for this study, and by means of spatial techniques (i.e., extracts values to points) number of points fall under very high to high hazard classes were counted. The result inferred that among the landslide locations (i.e., inventory) 80\% (42); 40\% (21) and $\sim 94 \%$ (49) fall under very high to high hazard classes of natural break, equal interval, and quantile classified susceptibility maps respectively. From the statistics, it could be concluded that in the quantile classified map the very high to high susceptible classes (e.g., $\sim 23 \%$ of the study area) showed a good agreement with the previous landslide locations. Likewise rest of the classes viz., very low; low; moderate exhibit $22 \mathrm{~km}^{2}$ (14\%), $90 \mathrm{~km}^{2}$ (53\%); $24 \mathrm{~km}^{2}$ (14\%) respectively. 


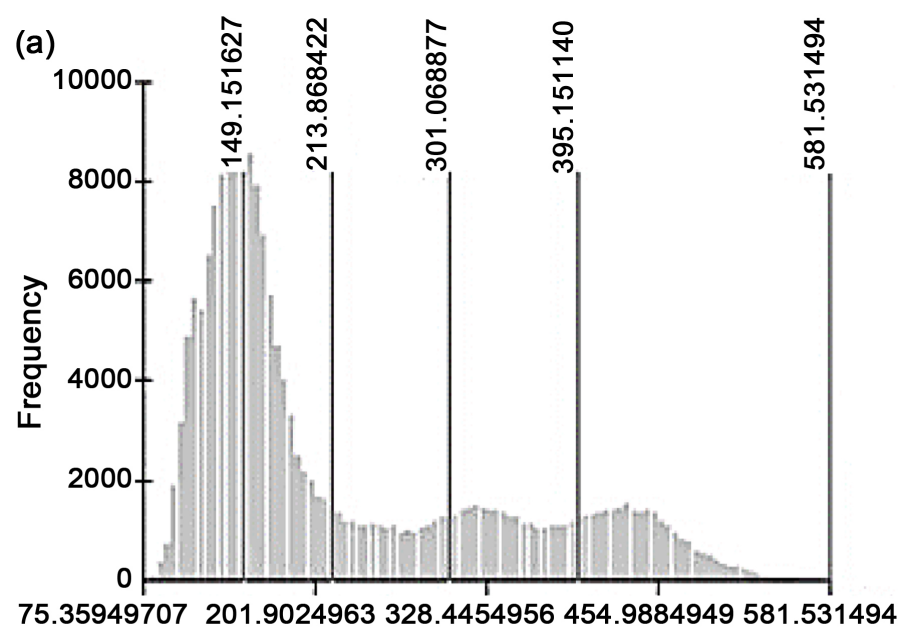

Landslide susceptibility index (LSI) values

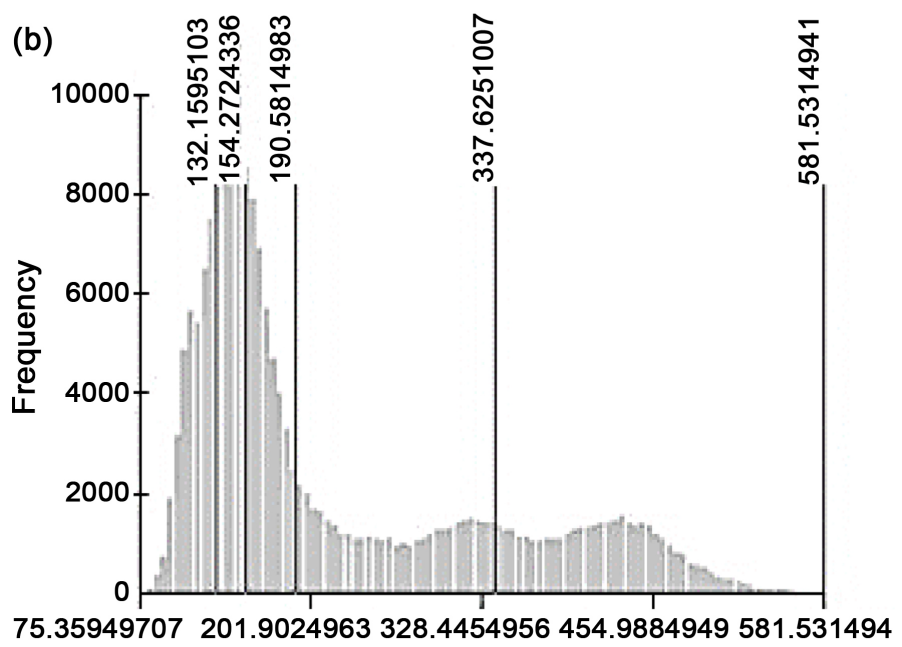

Landslide susceptibility index (LSI) values

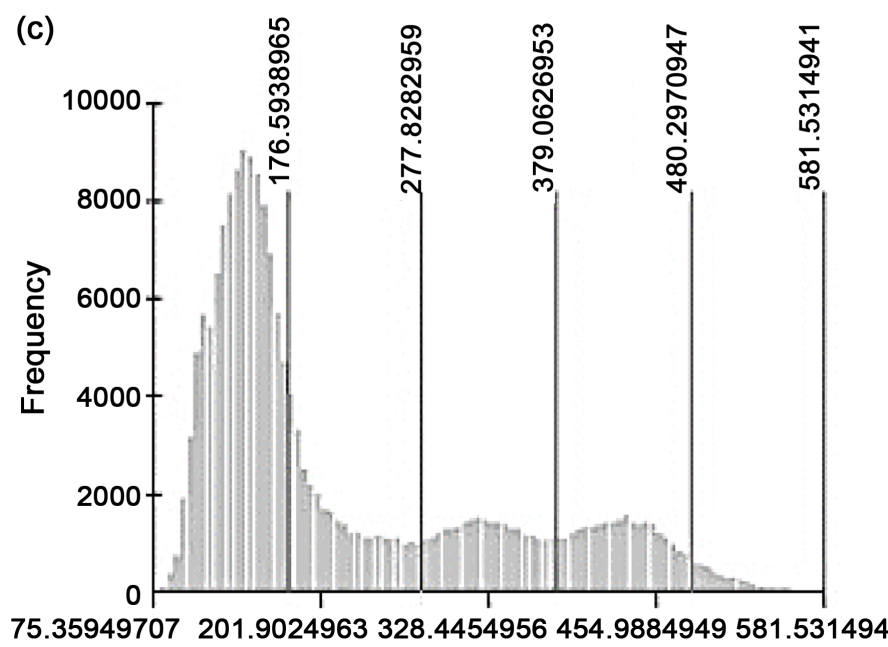

Landslide susceptibility index (LSI) values

Figure 4. Histogram distribution for three classification scheme e.g., (a) natural break; (b) quantile; and (c) equal area. 
(a)

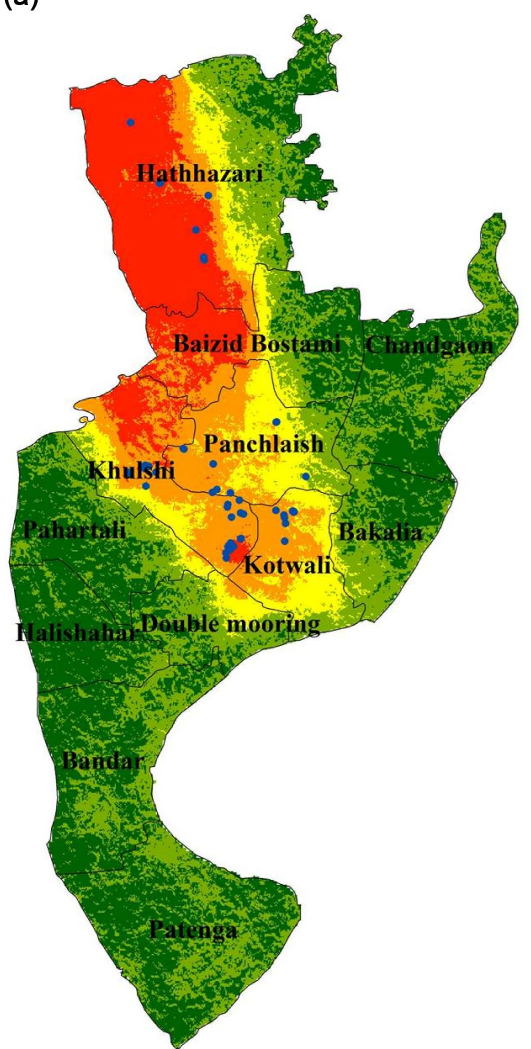

(b)

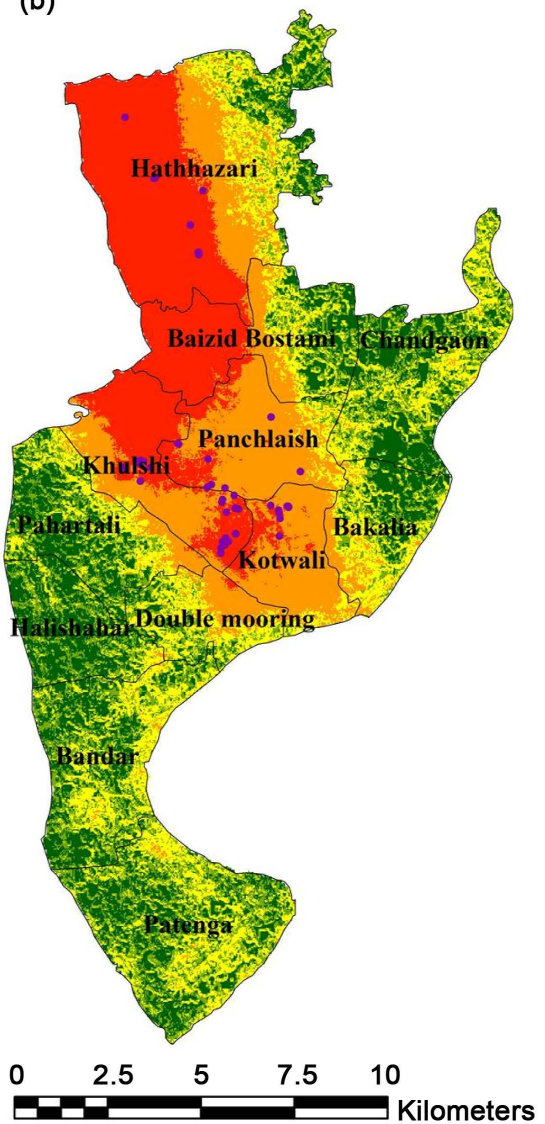

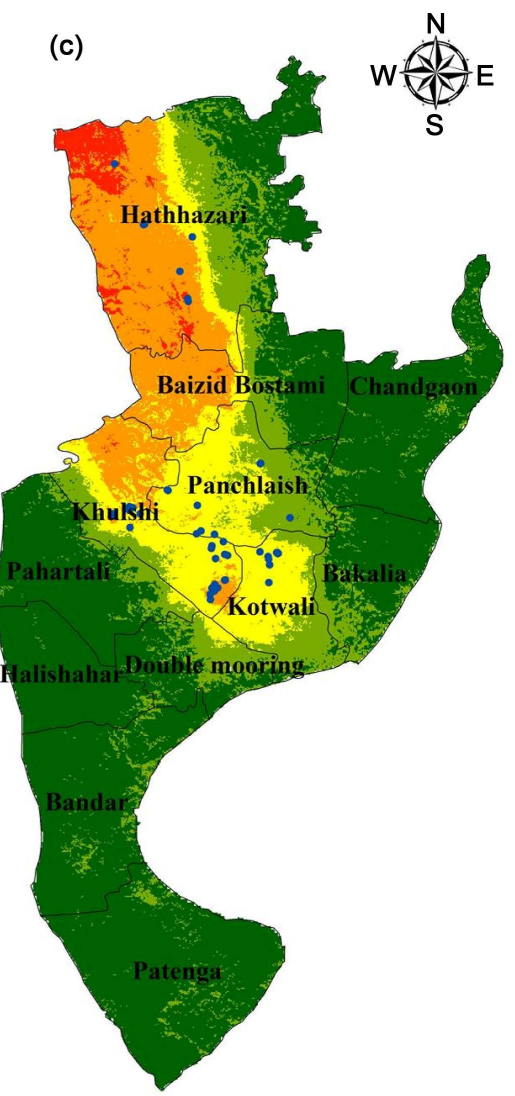

Very low Low Moderate High Very high

Admin boundary

- Landslide locations

Figure 5. Landslide susceptibility zonation map based on various classification schemes (a) natural break; (b) quantile and (c) equal area of Chittagong Metropolitan City. Previous landslide locations from a landslide inventory are shown as blue dots to validate the final outcomes.

Among the administrative units Hathazari area exhibits maximum high hazard zones followed by Kulshi, Baizidbostami and Kotwali areas. In contrast, areas like Patenga, Bandar, Halishahar, Chandgaon, and Bakalia comprises very low to low hazard potential (Figure 5).

Unlike other researches [3] [68] the present study has given emphasis not only on landslide hazard zonation in a rapidly urbanized hilly area in Bangladesh but also examined the importance of open source spatial databases. However, so far, none of the researches have either declared strongly about its significance or acknowledged deeply. In the context of Bangladesh, spatial data are not available or if available, in fact, are not in usable format due to missing national spatial data infrastructure (NSDI) though many organizations (i.e., governmental and privates) are involved in geospatial data generation and upgradation. We believe that for a country like Bangladesh, open source geospatial attributes could be an alternative way to forward research especially in disaster domain, where geospatial attributes are much needed inputs. Interestingly, all the studies pertaining to landslides in Chittagong district has got almost similar results which reveals that very high to high hazard zones are more or less located in the similar and dis- 
tinct areas. Therefore, we believe that finding the exact causes as well as permanent mitigation approach should be the ultimate interest for the decision makers in the near future to minimize disaster losses. It is evident from the field investigation that local geology (i.e., lithology), slope, change of land use pattern as well as few other anthropogenic activities are the primary factors to be considered regarding landslide in the study area. In geological context, investigating the landslide affected areas it is observed that all the landslides occurred in sandstone of DupiTila and/or Tipam Formations. These formations were deposited under diverse environmental conditions. Consequently, their rock types as well as the geotechnical properties are different in nature. Moreover, the ultimate geotechnical properties are also subjective to the climatic changes as well as the tectonic activities the rocks have experienced since deposition. These two rock Formations are more vulnerable to landslides than other formations exposed in Chittagong area [69]. The principal mechanism of landslide infers that during the rainy season the slopes belonging to these formations become saturated and slides over the alternating shale and sand beds of Bhuban and/or Bokabill Formations. Sudden increase of rainfall therefore make the situation worse. In addition, terrains belonging to these Formations with higher slope (e.g., $>15^{\circ}$ ) are generally more under the threat of potential landslide than lower slopes (e.g., $<15^{\circ}$ ). Interestingly, in few places moderate slopes are reported to be more vulnerable. Besides, land use is another important factor in Chittagong landslide scenario. Due to rapid urbanization, LULC is changing frequently to accommodate massive people and to cope with industrialization. Furthermore, deforestation, illegal hill cutting, and timber operation reworks the existing land use pattern and eventually expose the sandstone units, making this rock unit less cohesive and less resistive, ultimately making the slopes more vulnerable. For instance, Kushumbagh, Lalkhanbazar, Baizid Bostami, Chittagong University, Lebubagan, and Kachuarghona are the areas where hill cutting may be the prime external factor of landslides. In other landslide areas, where sign of hill cutting is absent, excessive precipitation might be the major causative factor.

On top of that, during our investigation, we observed that landslides have occurred even in undisturbed natural slope. This signifies that, although the hill slopes were vulnerable due to human activities like deforestation and hill cuttings, but these were not the main external factors of landslides. Thus the only external factor potentially responsible is heavy rainfall. But the role of hill cutting and deforestation still cannot be ruled out, rather in some cases, these two factors might have accentuated the possibility of slides. Whatever the physical conditions of the landslide prone areas, the existing record puts forward an insight that the ultimate cause of landslide is the excessive rainfall within a short while. If a hill slope, devoid of vegetation, is open, rainwater can easily infiltrate into the slope materials and increases pore water pressure. As a result, crown cracks develop on top of hills, allowing more and more water to infiltrate into the materials, thus accounts for exceeding of pore water pressure over the shear resistance of the slope materials to trigger landslides. Other than this, absence of inadequate drainage for rainwater can also cause more infiltration into the 
ground and thus, ultimately, making the slopes more capable of sliding down. For the purpose of landslide hazard mapping the method of analysis as well as the criteria should be apposite and location specific for the susceptibility mapping though many parameters for instance slope, aspect, relative relief, etc. are somewhat common throughout the study areas. Allocation of weight value is one of the most instrumental components during hazard analysis; hence, requires satisfactory knowledge background, opinion from experienced professionals, and in situ surveying. Many scientists e.g., Ahmed 2015 [1] opine that the future rainfall prediction could be included in the final hazard mapping. Comparison of various methods for vulnerability mapping is well appreciated by the renowned journals. However, we do also not disagree with the importance of mapping by means of multiple techniques. But in fact, the final outputs are almost similar with little or no variation in hazard classes. Spatially, there is no significant difference in hazard classes found so far in the previous and current GIS based studies [1] [68] as mentioned earlier. From these perspectives, we recommend more attention towards permanent risk reduction approaches rather than focusing on the future rainfall as well as the LULC prediction [70]. We also advise to ensure essential risk reduction measures in this area. Regarding risk reduction approaches, first of all, concerned authority should focus more on the awareness program among the local habitants-living in the vicinity of the vulnerable sites. In order to raising awareness, they should campaign against the illegal hill cutting and construction of any house or infrastructure near the slope of hills by imposing strict rules and regulations. There is a common practice in Bangladesh that by using political power many people do illegal activities; hence, practice of any sort of political power, in this regard, should be strictly confronted. Further, the mitigation measures as a part of risk reduction approach must be considered based on the specific slope condition. We highly recommend analyzing the geotechnical properties of a particular slope prior to initiation of the slope protection measures. Furthermore, sound knowledge pertaining to the soil conditions as well as other physical conditions of the study area is essential. Many slope stabilization techniques are available which are simple and can be applied in the area without considering the bedrock geotechnical characteristics. However, few of them are exceedingly expensive and may require substantial amount of time to develop in the areas having risky slope condition. Therefore, it is wise to take expert opinion in advance for implementing any slope stabilizing techniques in the study area. Since the area comprises of sedimentary bedrocks, we recommend few techniques which are mostly grouped under earth slope stabilization/mitigation.

It is cleary evident from the field investigation as well as other relevant literature that landslide events of Chittagong mostly belong to slide and to some extent fall, categories of the earth flow. Rainfall is reported to be the ultimate cause of landslide, hence slope stabilization techniques are highly recommended. Retaining walls are obligatory (i.e., Timber crib, Steel bin wall, Reinforced earth wall and Gabion walls) in front of weak slopes having adequate drainage through the structure, because sometimes a heavy rainfall may build high ground-water 
pressure behind the retaining wall leading to its eventual failure. Piles could be an alternative option to protect slope and should extend well below the potential failure surface and be firmly driven into bedrock. Moreover, relatively less costly biotechnical slope protection measures could be an unconventional approach in the study area. In this technique, slope protection is employed by means of planting vegetation having strong root system. Before devising such measures, consultation with local soil expert is highly acclaimed. In a nut shell, only permanent mitigation measures could be the ultimate solution for future landslide hazard risk reduction in the study area.

\section{Conclusion}

In the context of disaster management, landslide susceptibility mapping, the ultimate purpose of this study, is one of the vital tasks. Hazard mapping needs spatial attributes to fit with appropriate model to get ultimate outcomes. Since spatial data creation is a costly and time consuming task, a lot of time goes in wastage due to data gathering. However, this study attempts elucidating the importance of open source geospatial data by means of utilizing landslide susceptibility mapping at landslide hazard prone Chittagong district of Bangladesh, which may help the local authority, planners, and policy makers to develop effective action plan for disaster risk reduction. For this research, knowledge driven multi-criteria evaluation (MCE) technique, i.e., heuristic, was adopted for susceptibility mapping incorporating nine most influential parameters-slope, aspect, plane curvature, distance to discharge, relative relief, land use/land cover, geomorphology, vegetation, and geology-identified for the study area. The dataset of these parameters are largely attributes of open source spatial data and field investigation, which were processed, analyzed, and prepared as thematic map in the GIS environment. Thematic mapping for each causative factor involved assignment of appropriate value to these parameters, finally which were integrated, using weighted linear sum, to get the ultimate hazard map. The final map reveals that $13 \%$ area falls under the high susceptible zone of landslides and $13 \%, 53 \%$ and $15 \%$ of the area belonging under very low, low and moderate susceptible zones respectively. Further, $6 \%$ area was threatened by very high landslide susceptibility. From this research it can be concluded that Landslides in Chittagong is the combine effect of monsoonal rainfall, less cohesive sand, present in the vulnerable slopes, and most importantly the unawareness of the local habitants who even though knowing the worst impact always stay near the vulnerable areas. A number of earthen slope protection techniques were suggested in this study. On top of that, we also suggested to promote public awareness regarding hill and tree cutting as well as settlement near vulnerable slopes to avoid destruction in near future. The hazard map is expected to contribute as a useful guideline to the administrative authorities, planning agencies, civil engineers, geographers, and geologists in slope management, land use planning, etc. in the hilly areas of Chittagong district, ultimately implicating contribution of this research to disaster risk reduction, capacity building, community resilience build- 
ing, and risk free urban development in this rapidly urbanized area of Bangladesh.

\section{Acknowledgements}

The authors express their sincere thanks USGS for making available open source spatial data to carry out the research. Remote Sensing and GIS Laboratory supported by Columbia University, USA at the Department of Geology in the University of Dhaka, is acknowledged for use of its facilities. Valuable comments and suggestions from anonymous reviewers are also highly acknowledged.

\section{References}

[1] Ahmed, B. (2015) Landslide Susceptibility Mapping Using Multi-Criteria Evaluation Techniques in Chittagong Metropolitan Area, Bangladesh. Landslides, 12, 1077-1095. https://doi.org/10.1007/s10346-014-0521-x

[2] Khan, I.S. (2008) Hill Cutting in Chittagong City Corporation Area: Its Causes and the Consequences. PhD Dissertation, Khulna University, Khulna.

[3] Khan, Y.A., Lateh, H., Baten, M.A. and Kamil, A.A. (2012) Critical Antecedent Rainfall Conditions for Shallow Landslides in Chittagong City of Bangladesh. Environmental Earth Sciences, 67, 97-106. https://doi.org/10.1007/s12665-011-1483-0

[4] Aalders, H.J. and Moellering, H. (2017) Spatial Data Infrastructure. Proceedings of the 20 th International Cartographic Conference, Vol. 4, Beijing, 6-10 August 2017.

[5] Datta, D.K. (1983) Geo-Engineering Problems of the Chittagong University Campus and Its Adjoining Areas, Chittagong, Bangladesh. M.Sc. Thesis, Department of Geology, University of Dhaka, Dhaka.

[6] Assaduzzaman, A.T.M. (1991) Landslide in Link Road Embankment at Jhagrarbil Area, Rangamati, Bangladesh. Bangladesh Journal of Geology, 10, 11-18.

[7] Rahman, M.A. (1997) GIS Application in Identifying Landslide Prone Zones in the Hilly Regions of South-East Bangladesh. M.Sc. Thesis, Department of Geology, University of Dhaka, Dhaka.

[8] Khatoon, R. (2000) Infra-Red Photo Interpretation and GIS Based Approach for Landslide Inventory and Slope Instability Analysis in A Part of Sitapahar Anticline West of Rangamati Town. M.Sc. Thesis, Department of Geology, University of Dhaka, Dhaka.

[9] Khan, Y.A. and Chang, C. (2008) Landslide Hazard Mapping of Chittagong City Area, Bangladesh. Indian Society of Engineering Geology, 35, 303-311.

[10] Mahmood, A.B. and Khan, M.H. (2007) Landslide Vulnerability of Bangladesh hills and Sustainable Management Option: A Case Study of 2007 landslide in Chittagong City. SAARC Workshop on Landslide Risk Management in South Asia. SAARC Disaster Management Centre, New Delhi.

[11] Park, S., Choi, C., Kim, B. and Kim, J. (2013) Landslide Susceptibility Mapping Using Frequency Ratio, Analytic Hierarchy Process, Logistic Regression, and Artificial Neural Network Methods at the Inje Area, Korea. Environmental Earth Sciences, 68, 1443-1464. https://doi.org/10.1007/s12665-012-1842-5

[12] Kouli, M., Loupasakis, C. andSoupios, P. (2010) Landslide Hazard Zonation in High Risk Areas of Rethymno Prefecture, Crete Island, Greece. Natural Hazards, 52, 599 621. https://doi.org/10.1007/s11069-009-9403-2

[13] Patwary, M.A.A., Champati, R.P.K. and Parvaiz, I. (2009) IRS-LISS-III and PAN 
Data Analysis for Landslide Susceptibility Mapping Using Heuristic Approach in Active Tectonic Region of Himalaya. Journal of the Indian Society of Remote Sensing, 37, 493-509. https://doi.org/10.1007/s12524-009-0036-4

[14] Kamp, U., Growley, B.J. andKhattak, G.A. (2008) GIS-Based Landslide Susceptibility Mapping for the 2005 Kashmir Earthquake Region. Geomorphology, 101, 631642.

[15] Pandey, A., Dabral, P.P. and Chowdary, V.M. (2008) Landslide Hazard Zonation Using Remote Sensing and GIS: A Case Study of Dikrong River Basin, Arunachal Pradesh, India. Environmental Geology, 54, 1517-1529. https://doi.org/10.1007/s00254-007-0933-1

[16] Shaban, A., Khawlie, M. and Kheir, R.B. (2001) Assessment of Road Instability along a Typical Mountainous Road Using GIS and Aerial Photos, Lebanon-Eastern Mediterranean. Bulletin of Engineering Geology and the Environment, 60, 93-101. https://doi.org/10.1007/s100640000092

[17] Temesgen, B., Mohammed, M.U. and Korme, T. (2001) Natural Hazard Assessment Using GIS and Remote Sensing Methods, with Particular Reference to the Landslides in the Wondogenet Area, Ethiopia. Physics and Chemistry of the Earth, Part C, 26, 665-675.

[18] Mora, S. and Vahrson, W. (1994) Macrozonation Methodology for Landslide Hazard Determination. Bulletin of Association of Engineering Geologists, 31, 49-58.

[19] Anbalagan, R. (1992) Landslide Hazard Evaluation and Zonation Mapping in Mountainous Terrain. Engineering Geology, 32, 269-277.

[20] Gunther, A. and Thiel, C. (2009) Combined Rock Slope Stability and Shallow Landslide Susceptibility Assessment of the Jasmund Cliff Area (Rügen Island, Germany). Natural Hazards and Earth System Sciences, 9, 687-698. https://doi.org/10.5194/nhess-9-687-2009

[21] Hasegawa, S., Dahal, R.K. and Nishimura, T. (2009) DEM-Based Analysis of Earthquake-Induced Shallow Landslide Susceptibility. Geotechnical and Geological Engineering, 27, 419-430. https://doi.org/10.1007/s10706-008-9242-z

[22] Mavrouli, O., Corominas, J. and Wartman, J. (2009) Methodology to Evaluate Rock Slope Stability under Seismic Conditions at Sola de Santa Coloma, Andorra. Natural Hazards and Earth System Sciences, 9, 1763-1773. https://doi.org/10.5194/nhess-9-1763-2009

[23] Godt, J.W., Baum, R.L. and Savage, W.Z. (2008) Transient Deterministic Shallow Landslide Modeling: Requirements for Susceptibility and Hazard Assessments in a GIS Framework. Engineering Geology, 102, 214-226.

[24] Havenith, H.B., Strom, A. and Caceres, F. (2006) Analysis of Landslide Susceptibility in the Suusamyr Region, Tien Shan: Statistical and Geotechnical Approach. Landslides, 3, 39-50. https://doi.org/10.1007/s10346-005-0005-0

[25] Luzi, L. and Pergalani, F. (1999) Slope Instability in Static and Dynamic Conditions for Urban Planning: The "Oltre Po Pavese" Case History (Regione Lombardia-Italy). Natural Hazards, 20, 57-82. https://doi.org/10.1023/A:1008162814578

[26] Miles, S.B. and Ho, C.L. (1999) Rigorous Landslide Hazard Zonation Using Newmark's Method and Stochastic Ground Motion Simulation. Soil Dynamics and Earthquake Engineering, 18, 305-323.

[27] Islam, M.M.A. (2013) Landslide Assessment, Susceptibility Mapping and Debris Flow Modeling at Ukhimath Region, Rudraprayag District, Uttarakhand, India. CSSTEAP Mtech Research Pilot Project.

[28] Oh, H.J. and Lee, S. (2011) Landslide Susceptibility Mapping on Panaon Island, 
Philippines Using a Geographic Information System. Environmental Earth Sciences, 62, 935-951. https://doi.org/10.1007/s12665-010-0579-2

[29] Pareek, N., Sharma, M.L. and Arora, M.K. (2010) Impact of Seismic Factors on Landslide Susceptibility Zonation: A Case Study in Part of Indian Himalayas. Landslides, 7, 191-201. https://doi.org/10.1007/s10346-009-0192-1

[30] Pradhan, B. and Lee, S. (2010) Landslide Susceptibility Assessment and Factor Effect Analysis: Back Propagation Artificial Neural Networks and Their Comparison with Frequency Ratio and Bivariate Logistic Regression Modelling. Environmental Modelling and Software, 25, 747-759.

[31] Bai, S.B., Wang, J. and Lu, G.N. (2009) GIS-Based and Data-Driven Bivariate Landslide-Susceptibility Mapping in the Three Gorges Area, China. Pedosphere, 19, 14-20.

[32] Jadda, M., Shafri, H.Z.M. and Mansor, S.B. (2009) Landslide Susceptibility Evaluation and Factor Effect Analysis Using Probabilistic-Frequency Ratio Model. European Journal of Scientific Research, 33, 654-668.

[33] Dahal, R.K., Hasegawa, S. and Nonoumra, A. (2008a) Predictive Modelling of Rainfall-Induced Landslide Hazard in the Lesser Himalaya of Nepal Based on Weightsof-Evidence. Geomorphology, 102, 496-510.

[34] He, Y.P. and Beighley, R.E. (2008) GIS-Based Regional Landslide Susceptibility Mapping: A Case Study in Southern California. Earth Surface Processes and Landforms, 33, 380-393. https://doi.org/10.1002/esp.1562

[35] Lee, C.T., Huang, C.C. and Lee, J.F. (2008) Statistical Approach to Earthquake-Induced Landslide Susceptibility. Engineering Geology, 100, 43-58.

[36] Lee, S. and Sambath, T. (2006) Landslide Susceptibility Mapping in the Damrei Romel Area, Cambodia Using Frequency Ratio and Logistic Regression Models. Environmental Geology, 50, 847-855. https://doi.org/10.1007/s00254-006-0256-7

[37] Pradhan, B., Singh, R.P. and Buchroithner, M.F. (2006) Estimation of Stress and Its Use in Evaluation of Landslide Prone Regions Using Remote Sensing Data. Advances in Space Research, 37, 698-709.

[38] Saha, A.K., Gupta, R.P. and Sarkar, I. (2005) An Approach for GIS-Based Statistical Landslide Susceptibility Zonation-With a Case Study in the Himalayas. Landslides, 2, 61-69. https://doi.org/10.1007/s10346-004-0039-8

[39] Singh, L.P., Van W.C.J. and Champati Ray, P.K. (2005) Accuracy Assessment of in SAR Derived Input Maps for Landslide Susceptibility Analysis: A Case Study from the Swiss Alps. Landslides, 2, 221-228. https://doi.org/10.1007/s10346-005-0059-Z

[40] Lee, S. and Choi, J. (2004) Landslide Susceptibility Mapping Using GIS and the Weight-of-Evidence Model. International Journal of Geographical Information Science, 18, 789-814. https://doi.org/10.1080/13658810410001702003

[41] Wu, S.R., Jin, Y.M. and Zhang, Y.S. (2004) Investigations and Assessment of the Landslide Hazards of Fengdu County in the Reservoir Region of the Three Gorges Project on the Yangtze River. Environmental Geology, 45, 560-566. https://doi.org/10.1007/s00254-003-0911-1

[42] Lin, M.L. and Tung, C.C. (2003) A GIS-Based Potential Analysis of the Landslides Induced by the Chi-Chi Earthquake. Engineering Geology, 71, 63-77.

[43] Dai, F.C., Lee, C.F. and Ngai, Y.Y. (2001) Landslide Risk Assessment and Management: An Overview. Engineering Geology, 64, 65-87.

[44] Chung, C.F. and Fabbri, A.G. (1999) Probabilistic Prediction Models for Landslide Hazard Mapping. Photogrammetric Engineering and Remote Sensing, 65, 13891399. 
[45] Pachauri, A.K., Gupta, P.V. and Chander, R. (1998) Landslide Zoning in a Part Comparison with Frequency Ratio and Bivariate Logistic Regression Modelling. Environmental Modelling and Software, 25, 747-759.

[46] García-Rodríguez, M.J., Malpica, J.A., Benito, B. and Díaz, M. (2008) Susceptibility Assessment of Earthquake-Triggered Landslides in El Salvador Using Logistic Regression. Geomorphology, 95, 172-191.

[47] Lee, S. (2004) Application of Likelihood Ratio and Logistic Regression Models to Landslide Susceptibility Mapping Using GIS. Environmental Management, 34, 223232. https://doi.org/10.1007/s00267-003-0077-3

[48] Dai, F.C. and Lee, C.F. (2002) Landslide Characteristics and Slope Instability Modeling Using GIS, Lantau Island, Hong Kong. Geomorphology, 42, 213-228.

[49] Chauhan, S., Sharma, M. and Arora, M.K. (2010) Landslide Susceptibility Zonation through Ratings Derived from Artificial Neural Network. International Journal of Applied Earth Observation and Geoinformation, 12, 340-350.

[50] Choi, J., Oh, H.J., and Won, J.S. (2010) Validation of an Artificial Neural Network Model for Landslide Susceptibility Mapping. Environmental Earth Sciences, 60, 473-483. https://doi.org/10.1007/s12665-009-0188-0

[51] Yilmaz, I. (2010) Comparison of Landslide Susceptibility Mapping Methodologies for Koyulhisar, Turkey: Conditional Probability, Logistic Regression, Artificial Neural Networks, and Support Vector Machine. Environmental Earth Sciences, 61, 821-836. https://doi.org/10.1007/s12665-009-0394-9

[52] Caniani, D., Pascale, S. and Sdao, F. (2008) Neural Networks and Landslide Susceptibility: A Case Study of the Urban Area of Potenza. Natural Hazards, 45, 55-72. https://doi.org/10.1007/s11069-007-9169-3

[53] Lee, C.T. (2006) Methodology for Estimation of Earthquake-Induced Landslide Probability and Result Evaluation. Geophysical Research Abstracts, 8, Article No. 05759.

[54] Lee, S. and Evangelista, D.G. (2006) Earthquake-Induced Landslide-Susceptibility Mapping Using an Artificial Neural Network. Natural Hazards and Earth System Sciences, 6, 687-695. https://doi.org/10.5194/nhess-6-687-2006

[55] Wang, H.B. and Sassa, K. (2006) Rainfall-Induced Landslide Hazard Assessment Using Artificial Neural Networks. Earth Surface Processes and Landforms, 31, 235247. https://doi.org/10.1002/esp.1236

[56] Ercanoglu, M. (2005) Landslide Susceptibility Assessment of SE Bartin (West Black Sea Region, Turkey) by Artificial Neural Networks. Natural Hazards and Earth System Sciences, 5, 979-992. https://doi.org/10.5194/nhess-5-979-2005

[57] Arora, M.K., Das Gupta, A.S. and Gupta, R.P. (2004) An Artificial Neural Network Approach for Landslide Hazard Zonation in the Bhagirathi (Ganga) Valley, Himalayas. International Journal of Remote Sensing, 25, 559-572. https://doi.org/10.1080/0143116031000156819

[58] Gallus, D., Abecker, A. and Richter, D. (2008) Classification of Landslide Susceptibility in the Development of Early Warning Systems. In: Ruas, A. and Gold, C., Eds., Headway in Spatial Data Handling, Springer, Berlin Heidelberg, 55-75. https://doi.org/10.1007/978-3-540-68566-1_4

[59] Yao, X., Tham, L.G. and Dai, F.C. (2008) Landslide Susceptibility Mapping Based on Support Vector Machine: A Case Study on Natural Slopes of Hong Kong, China. Geomorphology, 101, 572-582.

[60] Yao, X., Dai, F.C. and Chen, J. (2006) Landslide Interpretation of Remote Sensing Images in the Dry-Hot Valley of Jinshajiang River. The Chinese Journal of Geologi- 
cal Hazard and Control, 17, 18-21.

[61] Brenning, A. (2005) Spatial Prediction Models for Landslide Hazards: Review, Comparison and Evaluation. Natural Hazards and Earth System Sciences, 5, 853 862. https://doi.org/10.5194/nhess-5-853-2005

[62] Shaw, R. and Mallick, F. (2013) Disaster Risk Reduction Approaches in Bangladesh. Springer, New York.

[63] BBS (2011) Population and Housing Census 2011 Bangladesh Bureau of Statistics (BBS). Ministry of Planning, Government of the People's Republic of Bangladesh, Dhaka.

[64] Nagarajan, R., Roy, A., Kumar, R.V., Mukherjee, A. and Khire, M.V. (2000) Landslide Hazard Susceptibility Mapping Based on Terrain and Climatic Factors for Tropical Monsoon Regions. Bulletin of Engineering Geology and the Environment, 58, 275-287. https://doi.org/10.1007/s100649900032

[65] Clerici, A., Perego, S., Tellini, C. and Vescovi, P. (2006) A GIS Based Automated Procedure for Landslide Susceptibility Mapping by the Conditional Analysis Method: the Baganza Valley Case Study (Italian Northern Apennines). Environmental Geology, 50, 941-961. https://doi.org/10.1007/s00254-006-0264-7

[66] Voogd, H. (1983) Multicriteria Evaluation for Urban and Regional Planning. Pion Ltd., London.

[67] Rahman, M.S., Ahmed, B., Huq, F.F., Rahman, S. and Al-Hussaini, T.M. (2016) Landslide Inventory in an Urban Setting in the Context of Chittagong Metropolitan Area, Bangladesh. 3rd International Conference on Advances in Civil Engineering, Cox's Bazar, 21-23 December 2016, 170-178.

[68] Patwary, M.A.A. and Bregt, I.A.K. (2013) Hazard Assessment Using Open Source Data: A Case Study for Chittagong, Bangladesh. Unpublished M.S. Thesis, Wageningen University Master of Geo-Information Science (MGI), Wageningen.

[69] Karim, N. (1995) Disasters in Bangladesh. Natural Hazards, 11, 247-258. https://doi.org/10.1007/BF00613409

[70] Hammed, F., Hewa, G.A. and Argue, J.R. (2014) Variability of Annual Daily Maximum Rainfall of Dhaka, Bangladesh. Atmospheric Research, 137, 176-182.

\section{Submit or recommend next manuscript to SCIRP and we will provide best service for you:}

Accepting pre-submission inquiries through Email, Facebook, LinkedIn, Twitter, etc. A wide selection of journals (inclusive of 9 subjects, more than 200 journals)

Providing 24-hour high-quality service

User-friendly online submission system

Fair and swift peer-review system

Efficient typesetting and proofreading procedure

Display of the result of downloads and visits, as well as the number of cited articles

Maximum dissemination of your research work

Submit your manuscript at: http://papersubmission.scirp.org/

Or contact ijg@scirp.org 